\title{
Racialization in Switzerland: experiences of children of refugees from Kurdish, Tamil and Vietnamese backgrounds
}

\author{
Laurence Ossipow, Anne-Laure Counilh ${ }^{*}$ (D) and Milena Chimienti
}

\author{
* Correspondence: \\ anne-laure.counilh@hesge.ch \\ University of Applied Sciences \\ Western Switzerland - HES-SO \\ Genève Haute école de travail \\ social, 28, rue Prévost-Martin, case \\ postale 80, 1211 Genève 4, \\ Switzerland
}

\begin{abstract}
This article explores the various types of racism and racialization comparing the experiences of descendants of Kurdish, Tamil, and Vietnamese refugees in Switzerland. Drawing on qualitative data from 45 interviews, the article shows that children of refugees experience several forms of racialization, the impact of which varies. The article shows that children of refugees tend to deny or relativize the interpersonal racism they experience daily, whilst they name and reject forms of racialization that have an effect on their socio-economic mobility as discrimination and racism. The paper argues that experiences of racialization explain why some adult children of refugees do not feel they 'fit in' despite their upwards socio-economic mobility.
\end{abstract}

Keywords: Second generation, Migration, Refugees, Racism, Racialization, Tamil, Kurdish, Vietnamese, Switzerland

This article, which forms part of a comparative European project, focuses on the experiences of racialization from the perspectives of adult children of refugees born in Switzerland. It draws on data collected with children of refugees from Tamil, Vietnamese and Kurdish backgrounds who have spent some or most of their childhoods in Geneva area. In exploring negative and 'positive' experiences of racialization amongst the three groups, this study seeks to understand the impact of these experiences on the lives of adult children of refugees, looking at their views, feelings and reactions. Experiences of racialization are important because they explain why some adult children of refugees do not feel they 'fit in' despite their upwards socio-economic mobility.

In a period of mass mobility when the 'common-sense' seemed to have accepted 'the argument that many Western societies have become "too diverse" for their own good' (Bloch \& Solomos, 2010, p. 1), understanding the ways in which people with a refugee background are racialized, and the consequences of such experiences on their lives is a pressing contemporary policy-challenge in order to provide effective and human responses to the movement of refugees, and to their children, born in the context of their parents' exile. However racialization continues to be an under-researched phenomenon in Europe (Goldberg, 2006) and especially in Switzerland (Purtschert, Lüthi, \& Falk, 2012). Besides, despite the growing numerical significance of the second generation from refugee backgrounds, little is actually known about the experiences of this group because, within academic literature and policy analysis, they are generally

(c) The Author(s). 2019 Open Access This article is distributed under the terms of the Creative Commons Attribution 4.0 International License (http://creativecommons.org/licenses/by/4.0/), which permits unrestricted use, distribution, and reproduction in any medium, provided you give appropriate credit to the original author(s) and the source, provide a link to the Creative Commons license, and indicate if changes were made. 
subsumed within the broader analyses of second generation ethnic minority backgrounds (Crul, Schneider, \& Lelie, 2012). In this sense this paper fills a gap in the literature by focusing on the experiences of racialization amongst the second generation from refugee backgrounds. It draws out the specificities of different refugee backgrounds.

We have organized the article in eight parts. Firstly we discuss the wider context of racism and racialization in Switzerland focusing on the migration policies in this country. This allows us to situate the context in which racialization of children of refugees can be explained. Then we provide a literature review on the idea of racialization. We then describe our research methods. The next four sections besides the conclusion present the key empirical examples on which we draw. We start by analyzing how and why experiences of racialization and racism were denied or relativized by the adult children of refugees. In the two following sections we explore first the negative and finally the 'positive' experiences of racialization looking at different period of the trajectory, i.e. childhood, adolescence and adulthood, and settings, i.e. school, work and free-time. In these sections we stress the similarities between the three groups whilst the last empirical section highlights some of the differences.

The article argues that stigma and discrimination related to the experiences of racialization are more complex to grasp than proven racism. Based on the notion of racialization it shows the ambivalent feelings and experiences of the adult children of refugees who could say they were victims of racist mockery and at the same time deny or relativize such racism. This notion allows us to understand how racializing stereotypes could be returned as positive references.

\section{Situating racism and racialization in the Swiss context}

Although xenophobia and racism have been thoroughly studied in Switzerland (see Bolzman, Eckmann, Salberg, \& Grünberg, 2000; Cattacin, Gerber, Sardi, \& Wegener, 2006; Eckmann, Sebeledi, Bouhadouza, \& Wicht, 2009, for example) the question of racialization is in its early stages. Switzerland, absent from the colonial empires, does not display a strong historical context of racialized hierarchy. Additionally, given its neutral international position and important humanitarian tradition, Switzerland may tend to consider racism as an individual phenomenon (Cattacin et al., 2006; Lavanchy, 2014). However, as put forth by Minder (2011), Switzerland may have a 'colonial power without colonies'. Racist social structures, or at least a racialized collective imagination, did indeed exist throughout history in Switzerland. This is apparent when analyzing several national fairs (Minder, 2011) and Swiss children's literature (Purtschert et al., 2012). However racialization continues to be an under-researched phenomenon in Europe (Goldberg, 2006) as in particular in Switzerland (Purtschert et al., 2012). Racialization issues have been rarely studied in second-generation children of immigrant populations, especially in research on Italian, Spanish, and Portuguese individuals born in Switzerland after their parents immigrated between the 1960s and 1980s (Bolzman, Fibbi, \& Vial, 2003).

The history of migration and naturalization in Switzerland also shows how large numbers of foreign immigrants were considered a threat to Swiss identity following the First World War. The fear of over-foreignization (Überfremdung) was employed on numerous occasions in politics to depict the risks of too much immigration on the economy, as well as on national values (Studer, Arlettaz, \& Argast, 2008). The 1991 
implementation of the 3-Circle Model, aimed at integrating Switzerland within its European environment, was essentially economic. However, the 3-Circle Model was based on an underlying racialized categorization that was described as an ethnocentric and "ethno-cultural" model, even at its inception (Mahnig \& Cattacin, 2005). One of the criteria used to select individuals for admission was "cultural proximity/distance", meaning supposedly shared cultural, religious, and social values with Switzerland (Alber, Ossipow, Outzambet, \& Waldis, 2000; Centlivres, Centlivres-Démont, Maillard, \& Ossipow, 1991; Ossipow \& Felder, 2015). The model was consequently considered to be "discriminatory", even "racist", due to it openly determining admission criteria for foreign workers (D'Amato, 2001; Michel, 2015; Piguet, 2009). The model was then modified, yet it remains the foundation of a racialized migration management model.

The history of migration policy related to asylum, specifically as it relates to the three populations with which our study is concerned, is influenced by additional factors. The 'Switzerland as a safe haven' origin myth (Parini, 1997) encouraged the country to open its doors to political exiles from communist regimes following the Second World War. After the fall of Saigon in 1975, Vietnamese refugees arrived within a fairly favorable context, especially considering that their exile enjoyed a wave of international support (Parini, 1997). On the other hand, Kurdish and Tamil refugees arrived in Switzerland between the 1980s and 2000s when the country's migratory and asylum policy was much more restrictive (Mahnig \& Cattacin, 2005). Between 1980 and 1990 requests for asylum multiplied tenfold. In a context of economic recession, the public saw this increase and its consequent administrative burden as a threat to the country's economic and political stability (Bolzman, 1992; Parini, 1997). While Vietnamese families benefited from resettlement programs, Kurdish and Tamil refugees often arrive in groups of men, after lengthy and dangerous trips into Europe organized by smugglers (Haab, Bolzman, Kugler, \& Yilmaz, 2010). Once these men get their situation in administrative order, women and children join through family reunification programs. Beyond a more unfavorable political and economic context compared to Vietnamese refugees, Kurdish and Tamil refugees were often affected by an increasingly unfavorable societal context with respect to asylum; suspicion with regards to their reasons for exile, as well as assumptions that their origin was associated with ethnic conflict and alleged terrorist organizations such as the Liberation Tigers of Tamil Eelam (LTTE) and the Partiya Karkerên Kurdistanê (PKK) (Hess \& Korf, 2014; Tattolo \& Wihtol de Wenden, 2016).

This overview foregrounds Swiss migration and asylum policies as an essential framework with which to analyze experiences of racism and racialization. These policies explain the persistence of racialization and racism in Switzerland among others in the labor and housing market (Fibbi, Kaya, \& Piguet, 2003; Zschirnt \& Ruedin, 2016) and can lead to 'disenchantment' of native-born youth of immigrants and refugees (see Crul et al., 2012, p. 20; Portes \& Zhou, 1993). This persistence of racialization and racism in the Swiss migration and asylum policies but also in the individual attitude (Zschirnt \& Ruedin, 2016) can also explain why some still do not feel to 'fit in' even when they managed to overcome the structural barriers and achieve a socio-economic mobility (Duemmler \& Dahinden, 2016). An analysis of public policy by adopting a 'racial' approach, in line with the concept of 'political racelessness' as coined by Goldberg (2006), is therefore necessary to highlight marginalization and minority claims that have remained invisible and silent (see 
among others: Bassel \& Emejulu, 2017; Collins \& Solomos, 2010; Dorlin, 2006; Hirsch, 2017; Michel, 2015; Purtschert et al., 2012; Solomos, 2003; Solomos \& Back, 1996).

\section{Defining racialization and racism}

Before moving on to the main focus of this chapter - the specific experiences of racialization and racism by children of refugees - we want to briefly discuss the literature on racisalization and racism in order to outline some of the conceptual arguments that we shall draw on later. Along with Fassin (2006a), we argue that one of the first questions to take into account when analyzing processes of racialization is how to consider, and name, social differences that manifested in speech and actions towards certain groups of individuals, thereby objectifying social groups and the means of identifying with those groups. If the notion of race, sensu stricto - 'the belief and affirmation that biologically constitutive differences in population exist' (Fassin, 2006a, p. 30) - is put into question, studies do still characterize genomic variations in populations considered to be homogenous. ${ }^{1}$ Fassin states that 'race, in a strict biological and phenotypical sense' remains a social and biomedical signifier (Fassin, 2006a, p. 30). This is why deconstructing the idea of racialization remains a key goal in academic research and contexts considered as being 'diversified' but not racialized, such as in the Geneva area.

We will use the notion of racialization to analyze interviewees' experiences, as it helps prevent 'closure' and 'polarization' that comes with basic racist/non-racist labeling (Rattansi, 2005, p. 28). In other words, the notion of racialization enables identification of diverse categorization mechanisms (see Murji \& Solomos, 2005). Such mechanisms include the following: racialization without racism, phenotype-based self- and exo-categorization depending on context and power dynamics (categorization does not go hand in hand with discriminations in this case); raceless racism when an individual is racialized based on his or her nationality, place of origin, practices or more generally on the controversial notion of 'culture' (Guillaumin, 1995; Ossipow, 2011), elements that are not linked to phenotypical differences; and racist racialization, also known as racism referring to race, when experiences, behaviors, injustices and discriminations are attributed to individuals that can be labeled using phenotypical characteristics.

As emphasized by several scholars, this categorization of racialization should also include an intersectional and situated approach to avoid a risk of reifying and radicalizing certain traits': 'reified meaning that certain traits are defined as the essence of otherness; radicalized presuming an overemphasis of these traits compared to any other possible characterization' (Dorlin, 2006; Fassin, 2006a, p. 32; Goldberg, 2006; Murji \& Solomos, 2005). This definition includes gender, age, generational dynamics, and social class stratifications. It allows to identify the varied and intersectional power relations as for instance in the case of black women whose claims where silenced from both civil rights movement lead by black men and feminist movements lead by white women (Collins, 2009).

In order to grasp the different forms of racialization, it is also necessary to distinguish who is the author of racialization and racism. Balibar (2005) for instance differentiates interpersonal racism and 'institutionalized racism', when racism is indirectly grounded in specific historical and institutional contexts (political parties, for example) to promote unity centered around hypothetical national identity. Although institutionalized racism is not as strong as it was during the Nazi era, during the segregation era in 
South Africa or currently in the United States (Ndiaye, 2006), certain forms of racialization persist in specific laws, including those used to manage migration.

Finally, the views, interpretations and reactions of those who are subjected to racialization need to be studied in order to get a full understanding of this phenomenon. These reactions are influenced by the degree of social, legal and political recognition of racialization and discrimination (Bassel \& Emejulu, 2017). However throughout history discriminations have been buried collectively and not acknowledged in the public sphere (see among others Collins \& Solomos, 2010). For the French context, which shares with our research setting a similar assimilationist perspective on diversities (see Mahnig \& Cattacin, 2005), Fassin shows that discriminations were first rendered invisible and then disqualified in the last half-century (Fassin, 2006b). This scholar notes that French media in the 1990s rarely used the word 'discrimination', and the racial adjective is barely present, although the term 'racism' appears, albeit in reference to far-right ideologies and wording. Since the 2000s the question of racial discrimination has taken a more prominent place in public discourse in France, as in Switzlerand, but the situation is still discriminatory for the so- called minorities, which include children of refugees as argued in the previous section. For Fassin (2006b), the situation has evolved from one of denial, where racial discrimination exists but the facts are not part of public debate, to one of relativization, where the facts about racial discrimination are publicly acknowledged but in such an understated way as to prove discriminatory by default. The discrimination is not necessarily racial and can depend on other factors such as economic ones. He speaks in this case of denegation to emphasize that the relativization is also discriminatory. In other words, those who commit acts of discrimination (employers or social housing providers, for example) take care to make sure they do not appear to do so, or justify their acts. As for the victims, they are hit head on by explanations and contradictions specific to their racialization, without being able to consider such explanations themselves as a blatant expression of racism. Consequently many victims are negated as individuals, beyond their phenotype, and enter a circle of denial or relativization ${ }^{3}$ where they attribute their own experiences of stigma and discrimination not to racialization or racism, but to privileges of class, age or gender.

To sum up, the term 'racialization' must be used carefully because it entails a range of experiences: interpersonal or structural racism with more-or-less racist labeling. The term also occasions various reactions: denial, relativization, acknowledged discrimination or struggle against racism. Racialization also varies according to the context of reception and the intersectional power relations. However the notion of racialization is useful as it contributes to establishing a critical distance that enables an understanding of the way in which certain categories of individuals are racialized 'positively' ('Asians,' for example) while others are racialized negatively (people of colour, 'Arabs', or individuals who are recognizable by their name and not their phenotype Fibbi et al., 2003). In the rest of the paper, we will explore the type of racialization experienced by children of refugees from Kurdish, Tamil, and Vietnamese backgrounds in Switzerland, their feelings but also their reflections and interpretations on these experiences. We will focus on the similarities among the three groups and identify then some differences. 


\section{Methods and data}

This article is based on the Swiss sample of a wider research project focused on a cross-national comparison of the experiences of the same three groups of children of refugees, namely the Europe-born children of refugees from Sri Lanka, Turkey and Vietnam living in Geneva, London or Paris. We have collected a total of 135 in-depth interviews: 45 in each country. The three groups of origin were chosen to allow a comparison between the three cities insuring to have sufficient numbers of each group across the three research sites. The group were also chosen because of their differences and in order to study the impact of these differences on the trajectories: different historical linkages, different reasons for migration, varied religions and ethnicities (see author reference). The fieldwork took place in 2014 and 2015 and all the research participants had spent all or most of their childhoods in Geneva.

All the interviews in Geneva were carried out in French and translated for the purpose of this article. The data was collected using in-depth interviews based on a semi-structured topic guide which covered on a range of topics: educational experiences and outcomes, employment, intergenerational mobility in relation to education and employment, social networks, community engagement, transnational relations and reflections on identity, belonging, racism and how refugee backgrounds shape lives. The fieldwork in Geneva provided in particular the opportunity to compare contrasting arrival contexts of immigration and integration, as well as multiple and contrasted forms of racialization and discrimination according to the various origins of the refugees and their children.

Given the lack of a sampling frame and in order to achieve sample diversity, we used a number of different strategies and multiple starting points to recruit interviewees and for snowball sampling: gatekeepers from community organizations, student societies, local politicians, networks of colleagues, personal contacts, social media, etc. We set indicative quotas to guide our sampling strategies and to allow meaningful cross-national, cross-group and within-group comparisons (see Table 1).

To analyse our data, a coding frame has been jointly developed and the data from the interviews entered into NVivo software. The coding frame is composed of 16 categories and 83 sub-categories, as well as demographic variables.

\section{Denied or relativized experiences of racialization}

In this section we analyze the first accounts from the adult children of refugees that we interviewed on racialization, and how and why these accounts tend to deny or relativize the interviewees' experiences of racialization. As argued before, the immigration system has been governed by a racial logic, which is often unspoken. This political and economic context of arrival of the three groups of refugees had an influence on their children's integration and their representation of how they fare in society. This context explains why it may appear complex for children of refugees (also visible immigrants) to express and expose racism and racialization. Although racialization mechanisms are firmly rooted in biographical tales of the children of Kurdish, Tamil and Vietnamese refugees in our study, they tend to deny or relativize in their statements. In other words whilst institutional racism appears throughout individual stories, experiences tend to refer more closely to what Balibar (2005) describes as spontaneous or psychological racism, and more rarely to institutional or state-sponsored racism. In fact, most stories 
Table 1 Interviewee's main characteristics

\begin{tabular}{ll}
\hline Parents' country of origin & 15 \\
Vietnam & 15 \\
Sri Lanka & 15 \\
Turkey (Including Kurds) & \\
Gender & 20 \\
Male & 25 \\
Female & \\
Age & 5 \\
18-20 & 18 \\
$21-25$ & 22 \\
$26+$ & \\
Education & \\
Only compulsory & 11 \\
Vocational & \\
High school - ongoing & \\
Tertiary - ongoing & 5 \\
Main activity & 29 \\
Student & \\
Employed & \\
Unemployed & 21 \\
N=45 & \\
\hline
\end{tabular}

highlight a certain denial of racialization and racism, probably due to the fact that they are told within social spaces - Switzerland and more specifically the canton of Geneva - that claim to place their population's diversity at the forefront without acknowledging the hardships that racial or social class minorities may face (Monsutti, Grange Omokaro, Gazagne, \& Cattacin, 2017). However, various authors have mentioned that discrimination at school varies from one canton to another (Felouzis, Charmillot, \& Fouquet-Chauprade, 2016; Gomensoro \& Bolzman, 2016).

Even in the case where interviewees agree that they have been the target of negative or positive discrimination, and even when they have an ambiguous stance towards their parents and home community (loyalty versus needing to distance oneself from the burdens of 'tradition') they tend to explain the racialization they face as related to their social class and the refugee status of their parents rather than to their phenotype. The children of refugees in our sample consider themselves as being mostly integrated; they speak French, they display excellent social and economic mobility and they have a diverse social network. Most of them are in fact naturalized and are now Swiss nationals. However most of the testimonies we collected went back and forth between denial, relativization and alleged subjection to racialization as we shall see in what follows.

Several interviewees underlined the diversity of their educational environment, defining it as 'mixed,' 'really mixed', or 'multicultural', in line with the conventional social rhetoric highlighting their canton's diversity (Monsutti et al., 2017). Many of them refused to consider their school environment as racializing or racist, even when describing a specific experience of racial discrimination. Some interviewees stated that racism might be more psychological than structural. Concerned to prove that they or 
their own social environments were especially open-minded, some interviewees made stigmatizing statements about people sharing their origins or about others with foreign origins.

When asked about possible stigma, Eva, a young woman of Vietnamese origin, trivializes racialization by referring to the diversity she experienced in school. 'I actually wasn't the only immigrant, there was a lot of diversity in the neighborhood, there were Venezuelans, I mean people came from all over so I never felt the stigma of not being Swiss. I felt like everyone came from somewhere, but not from Switzerland.'.

Sibel hails from a Kurdish background and, despite the same type of comments, stressed the importance of differences in social class. 'Well, no, [there was no stigma], we actually lived in a neighborhood [...] where on one side you had villas and on the other, you had the working-class houses [...]. And we lived in the neighborhood with the buildings and there was more of a difference, I would say, a social difference. I mean at the time, I didn't really get it, but the kids who lived in the buildings all had parents who were migrants, working class, it was like a hierarchy, based on social class.' Despite this observation of a certain form of socio-spatial segregation where immigrants are housed in working class neighbourhoods with collective housing, Sibel adds that she benefited from her situation as a child of refugees in a city that, at the time, wasn't very open to immigration. 'I got a little lucky because when we arrived, there weren't many children of immigrants so back then we still had private tutors... so actually, while the other kids were doing crafts, I was getting French lessons'. As a current volunteer for organizations that help support students in need, she notes that tutoring is rarer now and that students are more quickly and systematically placed in special education classes, separated from ordinary classes, especially when faced with language difficulties due to parents not speaking French at home, or speaking it poorly.

Diverse origins and status among classmates is experienced as a positive component of the school experience. Besides, most interviewees explain that they were 'foreigners among other foreigners' and did not stand out in that respect. Only a few children of refugees mentioned their status as a visible foreigner. Nhu Quynh, a woman of Vietnamese background, recalls, 'Well, let's say that when kids are young, they're stupid and cruel, let's put it that way. [...] There was a lot of diversity at school, but in my class, there were three kids who were clearly foreigners from their [faces], and the rest were European. It led to a couple of arguments.'

For many interviewees racialization and racism were part of their every day. However in the Swiss context such memories of insults, taunts, and jokes about their origin or looks are frequent for children of refugees, yet are often relativized as benign experiences devoid of consequences and attributed to blunders, ignorance or childhood foolishness. Minh Quang, of Vietnamese descent recalls, 'But on my end [...] I had a great childhood, there weren't any... I mean, maybe I got made fun of a little bit at the start, [...], but I don't think it was mean, it was more about having fun than discriminating against anyone.'.

From these few quotes we can see that children of refugees position themselves somewhere between denial and relativization and do not put the spotlight on experienced racism: either because they were surrounded by other children of immigrants, or because they easily found their place in classes with Swiss nationals, or because they tend to attribute stigma to differences in social class, professional downgrading 
experienced by their parents, or a lack of orientation with respect to the cantonal school system and not to racialization.

Denial or relativization of racialization abound among our interviewees and represent a common experience and reaction towards racialization. However, when we get a detailed look at the life stories of descendants of refugees, recalls of discrimination related to racialization or racism emerge progressively as we shall discuss in the next section.

\section{Negative experiences: from interpersonal to structural forms of racialization and racism}

The negative impact of racialization takes different forms in the accounts of our interviewees: we can categorize them along with Balibars' distinction of 'interpersonal' and 'institutional' forms of racialization and racism (Balibar, 2005). Accordingly, the reaction will be different: sometimes not acknowledged, sometimes silenced or voiced by the victims. Piraï is a young woman of Tamil background, who tells the story of long-term racism. After moving to a new place, she remembers classmates in elementary and secondary school making fun of her. 'Once I left [the neighbourhood] and we got a new apartment, it was really hard. I remember that some kids were pretty racist. I remember that in my group, two kids were really racist and kept calling me black.' Xuan Thu, of Vietnamese origin, also remembers suffering through racist taunts from his classmates although he tends to explain the situation in part by childhood immaturity and the school socio-spatial context. 'I was the kid in the class that was different from the others, and probably even more so in a neighborhood with few foreigners... I think the hardest part of being a kid for me was that, it was being physically different, feeling different and seeing that others could see it too and judged me based on that...(...) children are children, they don't like differences...'

Apart from racism described as such by victims and experienced during childhood, other types of racialization appear mostly when children begin to attend either secondary schools (where high grades are required) or vocational schools (around the age of 12). Several individuals mentioned that they were signed up for vocational training despite good test scores, as if children of refugee families were unable to attend a demanding programme because their parents do not speak French very well, and may not have the means to properly supervise or support their children during their studies. This is a paradoxical position, given that most interviewees are currently enrolled in brilliant studies and often explain that they owe their diligence to the pressure put on them by their parents, who would do anything for their success (including paying for tutoring or private school). This process, however, is racialization in its most negative sense, leading to a social domination-subordination relationship that is based on origin' (Poiret, 2011, p. 108). Sibel, a young woman of Kurdish origin with a university degree, has fond memories of school and her teachers, although she now perceives how she was discriminated both on a racial and social basis by certain teachers in the choices she made for her education. 'Looking back, I see it now, but at the time I couldn't put words on it... certain teachers had stereotypes, were biased... when it came to being a daughter of migrants, to not have the same chances as everyone else in life... For example, when I was in secondary school, [...] there was the programme that leads up to the Matura, and [...] teachers were saying that I wouldn't be able to keep up as there was a lot of German and a lot of English, [they say] "It would be too much for me and my parents." Since the teachers were saying this, 
[my parents] didn't go against their view. So I didn't go into the Matura programme! There was a lot of bias there.'

In some cases, as in Sibel's, teachers or schools justify educational downgrading by invoking the difficulties faced by parents in supporting their children when they enroll in demanding programmes, or because of the insufficient French language skills of their children. In other cases, even the apparent shyness of a child is used as a means of justifying enrollment in a less prestigious programme than the child could potentially cope with.

The parents' poor knowledge of the school system plays an important role in being unable to (or unwilling to) go against course choices made by teachers. Resistance does not often occur in these cases, but when there is resistance, it often comes from the victim her/himself as in the case of Zaraa, a young woman of Kurdish descent. 'They always enrolled me in lower courses than what I deserved! [...] I fought to get into the gymnasium [i.e high school], I had enough points for the Matura (...), some teachers (...) they recommended another course choice and I replied in a mean way for my age back then "but if I have the points, you really think I won't give it a try? I'd rather try and fail than give up just because my teachers don't find me worthy enough!" I got back at them several years later, I went to that teacher's mailbox and wrote a letter saying that I got a political science degree so "watch out when you say things about kids, you can be sure that some of them will fight against your ideas".' Despite these hardships, Zaraa explains how the social context of her schooling helped develop resistance to educational discrimination. 'At the gymnasium, [...] I was with a lot of people, first of all who were very well-off from a social standard and they boosted me up a little more. I had good grades, and since I had good grades I didn't fall [...] into the trap that all children of refugees fall into if nobody encourages [...]. It's just that once somebody makes you feel inferior, if you don't take it upon yourself to fight, you'll end up [...].'

As underlined in the introduction, given the young age of our sample (18-37 years old), recalls of racialization related to the employment are fewer than those concerning school. Among our interviewees, 23 were under 26 years old when the study was conducted, meaning that most of them had not yet completed their studies or were just starting out in their professional life. However, the detailed analysis expressed by Amed, a man of Kurdish descent provides an idea of the discriminations children of refugees can experience in a professional setting. 'I saw it on a professional level, that it was, even if I found a job very quickly, it was harder to go much further. [...] You're constantly hearing that you're different [...]. I realized, at least in Switzerland, [...] that it was pretty perverse. What I mean is that nobody says it to your face, but they make you understand all the time [...]. My name is Amed, and if I was called Mario and I came from Italy, there would be much less of a problem.' Apparently considering that entering the professional world is easier for European non-visible immigrants, he adds, 'With the bias people have in their minds, they say to themselves "Oh, he's from Turkey, that's a Muslim country"... so you need to make a lot of efforts, twice as many, even in your work, to get to the same level and gaining acceptance. [...] Even now I can feel it, where I currently work. I have a very good position, I've moved up but [...] every single time I need to make that extra effort [...] I have a first name that sounds Muslim... there you go, I'm a foreigner, and when people look at me my skin tone isn't Swedish.' He does admit, as underlined by Fibbi et al. (2003), that the racialization he has experienced and 
continues to experience is not solely linked to a phenotype. 'It's true that I'm not necessarily typically Turkish-looking. I could pass for an Italian but then there's my first name.' Amed's story illustrates how racialization is not limited to stigma related to physical appearance, but also pertains to places of origin that individuals may be linked to, sending them back to an incarnation of [their] group of origin that [they must] deal with' (Poiret, 2011, p. 107).

The children of refugees from Kurdish, Tamil and Vietnamese backgrounds had different negative experiences of racialization during either their childhood, their adolescence or their adulthood. The meaning and impact of the racialization varies as we have highlighted when the author is a peer, a teacher or a line superior. Whilst cases of interpersonal racialization are part of their daily experience and systemically relativized by our interviewees, when the racialization can have an effect on their socio-economic mobility, as in the case of the teacher orienting to a vocational school instead of university, they point and name the discrimination and racism. However it does not lead them to look for reparation from a legal point of view denouncing for instance the teacher to the school or justice.

\section{'Positive' experiences of racialization: exotic racialized differences, self-racialization and stigma reversal}

Negative experiences of racialization were often evoked in relation to the educational and professional context whilst the positive references to racialization were more often experienced in social and leisure contexts such as hobbies. For instance, in the case of those who participate in activities related to parental context of origin that encourage endogamous social relations (for instance classes to learn the language of origin of their parents, traditional music and dance, community sports leagues). Although such activities are depicted positively, as entertaining, they are also used at the time to emphasize exotic racialized differences. In perpetuating traditional customs, children of refugees are portrayed as different from 'Swiss society.'

Certain individuals mentioned that they benefited from special support from neighbours and teachers and, globally, from positive associations with their origins. Eelachevi, a woman of Tamil descent, explains that she and her sister were once walking to school on their own, since their parents both worked early mornings, when they crossed paths with an elderly neighbour from their building who walked them to school. This chance encounter was a deciding moment for the young woman and her sister: the neighbour took them under her wing and became close to the whole family. She offered to pay the security deposit for the family's apartment, allowing them to move into a larger home, came over on Sundays for a family meal, attended all the birthdays and Christmas celebrations, taught the girls to ski and supervised them when they did their homework. This encounter with an individual who plays an influential role on the life of children of refugees is not a widespread experience in our sample, yet was mentioned by a dozen interviewees.

The Asian Nerd cliché gives a different illustration of racialization with positive effects. These experiences appear frequently in the stories of interviewees of Vietnamese descent such as Carole - like other children of Vietnamese refugees with university degrees - who has little fear of discrimination in the job market. 'Yeah, I think that when you graduate from $X$ (prestigious university), it changes things because 
it doesn't lead to a job where your appearance matters and maybe in that case, it can go in my favour because of the "Asian nerd" thing, where people think that Asians are harder workers and all that.' The underlying positive connotation of this type of racialization leads to positive consideration by those affected, as illustrated by Carole's reaction to comments by her fellow students. 'At the end of the year, I think "Maybe it's not going to work out, maybe I won't pass and all that,", and everyone is like "Of course you'll pass, you're Asian!" [Laughs.] On the one hand it makes me feel better! It doesn't make me mad either.' By embracing the Asian Nerd cliché and expanding it to her whole family, she appropriates this specific form of racialization, interpreted as a type of positive stigma.

Several interviewees describe how, by distancing themselves from the appropriation of bias used to transform it into a personal strength related to a specific origin, they managed to use this type of racialization to their advantage in school or at work in line with the theory of stigma reversal coined by Erwin Goffman (1986[1963]; see also Chimienti, Counilh, \& Ossipow, 2019). Truc Linh, a young woman of Vietnamese descent, explains how her foreign origin (that she herself describes as exotic) is an excuse to meet new people, as well as a strength in her career. She recounts how she used the 'Asian nerd' cliché to her advantage when looking for a job. 'I think employers appreciate the discipline, the loyalty and precision, this very Asian side of things. They're very Asian characteristics! We're also great employees because we have a lot of respect for hierarchy since we experienced it in our families [...] often people will think "she sure isn't the one I'll have problems with"' The example of Truc Linh, at the crossroads of stigma reversal and self-racialization, is a good illustration of how complex the consequences of racialization are on the life of those who experience it, even when it is positive.

\section{Differences in experiencing racialization}

Whilst we have so far argued that the migratory and asylum system is an essential framework in which to analyze experiences of racialization and racism and insisted on the similarities among our interviewees, these experiences have also to be analyzed according to: the individual life paths (socio-economic or demographic data, education, employment, social network); the role each individual considers as his or her own in society; and the importance given to their personal stories of racialization. This lens allowed us to identify some differences between and within the studied groups.

The most discriminated against are also those who tend to deny or relativize more often their every day experiences of racialization or racism, whilst those with a higher socioeconomic status more often name such experiences. By telling the story of their own experience with racialization, these individuals act as the spokespersons for those who are racialized, who are harmed by racialization, and are unable to make their voices heard. We found more second generation from a Vietnamese background in this situation than in the other groups.

We found also some gendered differences. Independently of their group of origin young women appear more highly impacted by racialization or self-racialization than young men since they often separate themselves both from the male students and from female students with Swiss backgrounds. The young women explain this attitude by a family education that prevents them from going out at night and taking part in student 
social life in the same ways as their male counterparts. Kalaïpunga, for instance, a young woman of Tamil descent, explains that since she started at her university, her network of friends is mostly made up of girls she has studied with, and most of them have a foreign origin (African, or Asian). They do not hail from Sri Lanka, however Kalaïpunga adds that they all share (unlike according to her Swiss women) strong family bonds, or a certain point of view on the role young women have within the family. 'We all go to a lot of weddings, and we know that we have the same kind of lifestyle. [...] We have a lot of things in common, and we don't feel as comfortable around European girls.' Kalaïpunga, as a young Sri Lankan woman, is not allowed to go out late, but adds that it does not bother her because she 'appreciates simple things in life, a nice meal, going to the movies, not big parties or going out.' She acknowledges the gender-specific aspect of this student social life, supervised by parents and social norms, when she talks about her brother, who enjoys going out to parties, and explains that he has 'more freedom' than she does. Her situation, common among our interviewees to other women with Tamil backgrounds, can be interpreted in different ways. On the one hand, one can see here a form of self-exclusion due to the internalization of the pressures that stem from the norms and values among the group of origin, in order words in terms of 'symbolic violence' (Bourdieu, 1979). On the other hand, this selected network can be explained in terms of 'elective affinities' chosen by the persons and allowing more agency (Weber, 1964/2004). Further intersectional analysis that go beyond the purpose of this article are needed in order to provide a full understanding of the situation of these women.

Other differences between the three groups seem to be more related to their parents' narratives, contexts of origin and diverse reception conditions from the host society. The context of reception is not only related to the national migratory and refugee policy but could depend on a subsystem such as the school system (Crul et al., 2012). Individuals of Sri Lankan descent seem to deny racialization more than others, perhaps in part due to the convergence of humble living conditions, but also a decreasing political threat with the dissolution of the Liberation Tigers of Tamil Eelam organization, and a non-threatening and non-invasive perception of Hinduism in the Swiss public eye.

Kurdish refugees are more inclined to condemn racialization and racism despite the often low socio-economic status of the parents in Switzerland. However the fact that the interviewed descendants of Kurdish and Turkish backgrounds are often more politicized than those with Vietnamese or Tamil backgrounds might explain they developed a 'political capital' and more awareness to voice when they are victims of racialization (see Tattolo \& Wihtol de Wenden, 2016). Besides, the relationship between individuals of Kurdish origin and Islam creates a specific vulnerability to racist discrimination, although many are in fact atheist (as encouraged by the PKK) or Alevi (which is strongly differentiated from Sunni and fundamentalist Islam). The ongoing fight for Kurdish independence and Kurdish involvement in the fight against ISIS in Syria, in turn makes them more visible to a Swiss audience and gives them an anti-establishment image. Moreover, PKK rhetoric is inspired by Marxism: condemning social inequality and discrimination is a strong part of the political activism on the part of descendants of Kurdish refugees, contrary to the experience of descendants of Vietnamese refugees who fled a Communist regime and tend to defend commercial capitalism, and contrary 
to that of descendants of Tamil refugees who embraced Swiss values of individualism (Moret, Efionayi-Mäder, \& Stants, 2007).

As we saw in the introduction, Vietnamese refugees were well received compared to other groups. This might also explain that the interviewees of Vietnamese descent are the only ones to mention a form of 'positive' racialization, linked to a more favorable context when their parents arrived in Switzerland as well as a higher socioeconomic status for some.

\section{Conclusion}

In this paper we have highlighted that racialization takes different forms in the testimonies of our interviewees confirming previous literature: from every day forms of racialization to overt structural racism through vocational orientation during school or barriers to upwards social mobility in the professional world.

We have also shown that the Swiss context is still one of denial and denegation of racial discrimination, both by the authorities and the targeted individuals. Although children of refugees are daily racialized, they tend to deny or relativize these experiences by attributing the discriminations they face to so-called underprivileged social class issues. They act that way in conformity with the Swiss context of 'political racelessness' (Goldberg, 2006). Lack of structural recognition and the related deficit of mechanisms of denunciation make the experiences of racialization more complex to grasp than obvious and proven forms of racism.

The various types of racialization discussed in this paper do not appear to have vastly hindered integration, upwards mobility, or life projects for the children of refugees interviewed throughout the study which provides some contrasting insights to the link made in previous literature between racialization and integration (Portes \& Zhou, 1993). However, this result has to be read carefully as racialization can still explain barriers to belonging, as in Sible's case. 'We have always to justify our identity, we have always a label, we have to endorse a label.' Our data places intergenerational social mobility pathways for children of refugees in the same general upwards dynamic as children of immigrants. However, second-generation immigrants currently tend to blend in with the general Swiss population, whereas the children of refugees interviewed for the study are still identified as foreigners despite their Swiss passport and socioeconomic success. Their identity is made more complex by racialization as highlighted by Truc Linh who mentions how complicated it is to know how to introduce oneself to others who focus on physical attributes irrelevant to her reality: 'You'll say "I'm Vietnamese" but (...) my Swiss friends (...) would say "no you're not, you're Swiss", but when you say "I'm Swiss", everyone else goes "you don't look Swiss... (laughs)" (...).'

Finally we can suppose that those children of refugees that we were unable to add to our sample, and who may have a more complicated educational and professional pathway, may remain affected by racialization related to their physical appearance and name for longer periods of time. Racialization may directly affect their upward mobility on an educational or professional level, as well as an unstable feeling of identity. This pleads for more research using a 'racial' approach in order to bring to the fore different social experiences, along a line of varied and intersecting power relations. 


\section{Endnotes}

${ }^{1}$ See also Collins \& Solomos, 2010; Solomos, 2003; Solomos \& Back, 1996.

${ }^{2}$ See among others Kimberley Crenshaw (1989) and Sandra Harding (1991).

${ }^{3} \mathrm{We}$ use the term denegation when the relativization is not made by the victim of racialization.

\section{Acknowledgements}

Thanks to the interviewees and our colleagues on the project: Alice Bloch, Shirin Hirsch, Giovanna Tattolo and Catherine Wihtol de Wenden. Thanks also to the appointed editor for this SI Andreas Pott and the anonymous reviewers of this journal for their very helpful comments, as well as to Karin Milovanovic for her support during this process.

Funding

The study on which this paper draws has been financed by the Swiss Network for International Studies project number $13-6401$.

\section{Availability of data and materials}

https://snis.ch/project/children-of-refugees-in-europe/

\section{Authors' contributions}

All authors have approved the manuscript for submission.

\section{Authors' information}

Laurence Ossipow is an anthropologist and Professor at the University of Applied Sciences Western Switzerland - Socia Work in Geneva (HETS) where she has been director of the research for the School for many years. She is a specialist of issues related to migration, social inclusion and citizenship and has conducted a number of research projects in this field. University of Applied Sciences Western Switzerland - HES-SO Genève

Haute école de travail social

28, rue Prévost-Martin • case postale 80 - 1211 Genève 4

laurence.ossipow-wuest@hesge.ch

Anne-Laure Counilh is a social geographer. She defended a PhD thesis on migration of transnational migrants from West Africa in Mauritania in 2014. Her attention is focused on migrations, transnational mobilities and socio-spatial interactions. For the Children of Refugees in Europe project, she served as research assistant. She currently teaches and continues her research on migration at the University of Applied Sciences Western Switzerland - Social Work in Geneva (HETS)

University of Applied Sciences Western Switzerland - HES-SO Genève

Haute école de travail social

28, rue Prévost-Martin - case postale 80 - 1211 Genève 4

anne-laure.counilh@hesge.ch

Milena Chimienti is a sociologist and Professor at the University of Applied Sciences Western Switzerland - Social Work in Geneva (HETS). She has researched and written mostly on the sociology of migration, processes of marginalization and forms of agency, both individual and collective, in situation of vulnerabilities. She was the main coordinator of the "Children of refugees in Europe" project.

University of Applied Sciences Western Switzerland - HES-SO Genève

Haute école de travail social

28, rue Prévost-Martin • case postale 80 - 1211 Genève 4

milena.chimienti@hesge.ch

\section{Competing interests}

The authors declare that they have no competing interests.

We confirm that the content of the manuscript has not been published, or submitted for publication elsewhere.

\section{Publisher's Note}

Springer Nature remains neutral with regard to jurisdictional claims in published maps and institutional affiliations.

Received: 20 December 2017 Accepted: 28 January 2019

Published online: 14 May 2019

\section{References}

Alber, J.-L., Ossipow, L., Outzambet, V., \& Waldis, B. (2000). Mariage tous azimuts: approche pluridisciplinaire des couples binationaux [All-round marriage: a multidisciplinary approach to binational couples]. Fribourg: Studia Ethnographica Friburgensia.

Balibar, É. (2005). La construction du racisme [The Construction of Racism]. Actuel Marx, 38(2), 11. https://doi.org/10.3917/amx. 038.0011.

Bassel, L., \& Emejulu, A. (2017). Minority women and austerity. Survival and resistance in France and Britain. Bristol: Policy Press. Bloch, A., \& Solomos, J. (2010). Race and ethnicity in the $21^{\text {st }}$ century. London: Palgrave Macmillan.

Bolzman, C. (1992). Violence politique, exil et politique d'asile: l'exemple des réfugiés en Suisse [Political violence, exile and asylum policy: the case of refugees in Switzerland]. Revue suisse de sociologie, 3, 675-693. 
Bolzman, C., Eckmann, M., Salberg, A.-C., \& Grünberg, K. (2000). Le racisme au quotidien: une typologie des incidents racistes en Suisse romande [Daily racism: a typology of racist incidents in the French speaking part of Switzerland]. In P. Centlivres, \& I. Girod (Eds.), Les défis migratoires [The migration challenges], (pp. 83-88). Zurich: Seismo.

Bolzman, C., Fibbi, R., \& Vial, M. (2003). Secondas-Secondos. Le processus dinntégration des jeunes adultes issus de la migration espagnole et italienne en Suisse [Secondos-Secondas. Integration process of young adults from Spanish and Italian migration to Switzerland]. Zurich: Seismo.

Bourdieu, P. (1979). La distinction. Critique sociale du jugement [Distinction: a social critique of the judgement of taste]. Paris: Minuit.

Cattacin, S., Gerber, B., Sardi, M., \& Wegener, R. (2006). Monitoring rightwing extremist attitudes, xenophobia and misanthropy in Switzerland. An explorative study (Research report - PNR 40+, Sociograph - Sociological Research. Study No 1 of the Department of sociology). Geneva: University of Geneva.

Centlivres, P., Centlivres-Démont, M., Maillard, N., \& Ossipow, L. (1991). Une seconde nature: pluralisme, naturalisation et identité en Suisse romande et au Tessin [A second nature: pluralism, naturalization and identity in French-speaking Switzerland and Ticino]. Lausanne: L'Âge d'Homme.

Chimienti, M., Counilh, A.-L., \& Ossipow, L. (2019). Second generation from refugee backgrounds: affects and transnational ties and practices to the ancestral homeland. In A. Bloch, \& G. Donna (Eds.), Forced migration: Current issues and debates. London: Routledge.

Collins, P. H. (2009). Black feminist thought: Knowledge, consciousness, and the politics of empowerment (first published 2000). New York and London: Routledge Classics, Vol. 138. (1st ed.).

Collins, P. H., \& Solomos, J. (2010). The SAGE handbook of race and ethnic studies. Los Angeles: SAGE.

Crenshaw, K. (1989). Demarginalizing the intersection of race and sex. Chicago: University of Chicago Press.

Crul, M., Schneider, J., \& Lelie, F. (Eds.) (2012). The European second generation compared: Does the integration context matter? Amsterdam: IMISCOE Research: Amsterdam University Press.

D'Amato, G. (2001). Vom Ausländer zum Bürger: der Streit um die politische Integration von Einwanderern in Deutschland, Frankreich und der Schweiz [From foreigners to citizens: the struggle for the political integration of immigrants in Germany, France and Switzerland]. Münster: LIT Verlag.

Dorlin, E. (2006). La matrice de la race: généalogie sexuelle et coloniale de la nation française [The Matrix of Race: Sexual and Colonial Genealogy of the French Nation]. Paris: La Découverte coll. "Textes à l'appui / Genre et sexualité".

Duemmler, K., \& Dahinden, J. (2016). Gehören wir dazu? Grenzziehungsprozesse und Positionierungen der zweite Generation im Vergleich zwischen Luzern und Neuenburg [Do we belong? Boundary making and positioning of the second generation:a comparision between Lucerne and Neuchâtel]. Swiss Journal of Sociology, 42(2), 309-331.

Eckmann, M., Sebeledi, D., Bouhadouza, V., \& Wicht, L. (2009). Lincident raciste au quotidien: représentations, dilemmes et interventions des travailleurs sociaux et des enseignants [The daily racist incident: representations, dilemna and interventions of social workers and teachers]. Genève: les éditions: Haute école de travail social.

Fassin, D. (2006a). Nommer, interpréter. Le sens commun de la question raciale [To name, to interpret. The common sense of the racial question]. In D. Fassin, \& E. Fassin (Eds.), De la question sociale à la question raciale? [From the social question to the racial question] (pp. 17-36). Paris: La Découverte.

Fassin, D. (2006b). Du déni à la dénégation. Psychologie politique de la représentation des discriminations [From denial to denegation. Political psychology of the representation of discrimination]. In D. Fassin, \& E. Fassin (Eds.), De la question sociale à la question raciale? [From the social question to the racial question?] (pp. 131-157). Paris: La Découverte.

Felouzis, G., Charmillot, S., \& Fouquet-Chauprade, B. (2011). Les inégalités scolaires en Suisse et leurs déclinaisons cantonales: l'apport de l'enquête Pisa 2003 [Educational Inequality in Switzerland and Cantonal Variations: The Contribution of the 2003 Pisa Study]. Revue suisse de sociologie, 37(1), 33-55.

Fibbi, R., Kaya, B., \& Piguet, E. (2003). Nomen est omen: quand s'appeler Pierre, Afrim ou Mehmet fait la différence [Nomen is omen: when to be called Pierre, Afrim or Mehmet makes the difference]. Berne; Aarau: Fonds nationale suisse: Schweizerischer Nationalfonds.

Goffman, E. (1986/1963) Stigma: Notes on the Management of Spoiled Identity. New-York: Simon \& Schuster, Inc.

Goldberg, D. T. (2006). Racial Europeanization. Ethnic and Racial Studies, 29(2), 331-364.

Gomensoro, A., \& Bolzman, C. (2016). Les trajectoires éducatives de la seconde génération. Quel déterminisme des filières du secondaire I et comment certains jeunes le surmontent? [Education pathways of the second-generation. What kind of determinism in lower secondary educational tracking and how some youngster overcome it]. Revue suisse de sociologie, 42(2), 291-311.

Guillaumin, C. (1995). Racism, sexism, power, and ideology. London; New York: Routledge.

Haab, K., Bolzman, C., Kugler, A., \& Yilmaz, Ö. (2010). Diaspora et communautés de migrants de Turquie en Suisse [Diaspora and migrant communities of Turkey in Switzerland]. Berne: ODM.

Harding, S. (1991). Whose science? Whose knowledge? Ithaca: Cornell University Press.

Hess, M., \& Korf, B. (2014). Tamil diaspora and the political spaces of second-generation activism in Switzerland. Global Networks, 14(4), 419-437. https://doi.org/10.1111/glob.12052.

Hirsch, S. (2017). Racism, 'second generation' refugees and the asylum system. Identities, 1-19. https://doi.org/10.1080/ $1070289 \times .2017 .1361263$.

Lavanchy, A. (2014). The circulation of people. How does "race" matter in Switzerland? Working paper 7, 2014/E). Neuchâtel: MAPS.

Mahnig, H., \& Cattacin, S. (2005). Histoire de la politique de migration, d'asile et d'intégration en Suisse depuis 1948 [History of migration, asylum and integration policy in Switzerland since 1948]. Zürich: Seismo.

Michel, N. (2015). Sheepology: The postcolonial politics of raceless racism in Switzerland. Postcolonial Studies, 18(4), 410-426. https://doi.org/10.1080/13688790.2015.1191987.

Minder, P. (2011). La Suisse coloniale. Les représentations de l'Afrique et des Africains en Suisse au temps des colonies (18801939) [Colonial Switzerland]. Bern: Peter Lang. https://doi.org/10.3726/978-3-0352-0063-8.

Monsutti, A., Grange Omokaro, F., Gazagne, P., \& Cattacin, S. (2017). Complicity and antagonism. Anthropological views of Geneva. Genève: Université de Genève, Sociograph, Sociological Research Studies. 
Moret, J., Efionayi, D., \& Stants, F. (2007). Diaspora sri lankaise en Suisse [Sri Lankan diaspora in Switzerland]. Office fédéral des migrations ODM. Retrieved from https://www.sem.admin.ch/dam/data/sem/publiservice/publikationen/diaspora/ diasporastudie-srilanka-f.pdf.

Murji, K., \& Solomos, J. (Ed.). (2005). Racialization: studies in theory and practice. Oxford: Oxford University Press.

Ndiaye, P. (2006). Questions de couleur: histoire, idéologie et pratiques du colorisme [Questions of color: history, ideology and practices of colorism]. In D. Fassin, \& E. Fassin (Eds.), De la question sociale à la question raciale?[From the social question to the racial question?] (pp. 37-54). Paris: La Découverte.

Ossipow, L. (2011). De la culture à la citoyenneté: réflexion sur trois recherches ethnologiques menées en contexte helvétique [From culture to citizenship: reflection on three ethnological studies conducted in a Swiss context]. In A Lavanchy, F. Dervin, \& A. Gajardo (Eds.), Pour une interculturalité renouvelée? [For a renewed interculturality?] (pp. 90-118). Paris: L'Harmattan.

Ossipow, L., \& Felder, M. (2015). Ethnography of a political ritual: Speeches given to new Swiss citizens by representatives of the state. Citizenship Studies, 19(3-4), 233-247. https://doi.org/10.1080/13621025.2015.1006175.

Parini, L. (1997). "La Suisse terre d'asile": un mythe ébranlé par I'histoire [Switzerland, country of political asylum]. Revue européenne de migrations internationales, 13(1), 51-69. https://doi.org/10.3406/remi.1997.1532.

Piguet, E. (2009). Limmigration en Suisse soixante ans d'entrouverture [Immigration to Switzerland]. Lausanne: Pr. polytechniques et universitaires romandes.

Poiret, C. (2011). Les processus d'ethnicisation et de raci (ali) sation dans la France contemporaine: Africains, Ultramarins et " Noirs " [Processes of ethnicization and raci(ali)zation in the contemporary french context: Africans, Caribbeans and "Blacks"]. Revue Européenne des Migrations Internationales, 27(1), 107-127. https://doi.org/10.4000/remi.5365.

Portes, A., \& Zhou, M. (1993). The new second generation: Segmented assimilation and itsvariants. The Annals, 530(1), 74-96.

Purtschert, P., Lüthi, B., \& Falk, F. (Eds.) (2012). Postkoloniale Schweiz: Formen und Folgen eines Kolonialismus ohne Kolonien [Post-colonial Switzerland. Forms and consequences of colonialism without colonies]. Bielefeld: Transcript.

Rattansi, A. (2005). The uses of racialization: The time-spaces and subject-objects of the raced body. In K. Murji, \& J. Solomos (Eds.), Racialization: studies in theory and practice, (pp. 271-303). Oxford; New York: Oxford University Press.

Solomos, J. (2003). Race and racism in Britain (3rd ed.). London: Palgrave Macmillan.

Solomos, J., \& Back, L. (1996). Racism and society. New York: St. Martin's Press.

Studer, B., Arlettaz, G., \& Argast, R. (2008). Das Schweizer Büggerrecht. Erwerb, Verlust, Entzug von 1848 bis Gegenwart [The Swiss citizenship law. Acquisition, loss, withdrawal from 1848 to present]. Zürich: Verlag Neue Zürcher Zeitung.

Tattolo, G., \& Wihtol de Wenden, C. (2016). France. In A. Bloch, M. Chimienti, A.-L. Counilh, S. Hirsch, L. Ossipow, G. Tattolo, \& C.W. de Wenden (Eds.), The children of refugees in Europe. Country reports. Geneva: SNIS. Retrieved from https://snis.ch/ project/children-of-refugees-in-europe/.

Weber, M. (1964/2004). L'Éthique protestante et l'esprit du capitalisme [The Protestant Ethic and the Spirit of Capitalism]. Paris: Plon, Gallimard.

Zschirnt, E., \& Ruedin, D. (2016). Ethnic discrimination in hiring decisions: A meta-analysis of correspondence tests 1990-2015. Journal of Ethnic and Migration Studies, 42(7), 1115-1134. https://doi.org/10.1080/1369183X.2015.1133279.

\section{Submit your manuscript to a SpringerOpen ${ }^{\circ}$ journal and benefit from:}

- Convenient online submission

- Rigorous peer review

- Open access: articles freely available online

High visibility within the field

- Retaining the copyright to your article

Submit your next manuscript at $\boldsymbol{\sim}$ springeropen.com 